\title{
“Neither Dead Nor Alive:" Ukrainian Language on the Brink of Romanticism
}

\author{
Taras Koznarsky \\ University of Toronto
}

\begin{abstract}
At the end of the eighteenth century through the first decades of nineteenth century, as the last vestiges of Ukrainian autonomy were abolished, Ukrainian elites and intelligentsia embarked on a diverse range of projects (addressing geography, history, ethnography, travel writing, journalism, and literature) aimed at privileging and promoting their cultural capital within the Russian imperial field of cultural production. The Ukrainian language and its origins, nature, and status came to the fore in these projects as Ukrainian literati carefully gauged their messages for both Ukrainian and metropolitan audiences in order to engage playfully and polemically with imperial perceptions of Ukraine and to further the cause of the Ukrainian language as a distinctive linguistic system, cultural legacy, and literary medium. These often cautious and purposefully ambiguous characterizations, classifications, and applications prepared the ground for the romantic generation of writers who dramatically expanded the stylistic and generic range of Ukrainian in their literary works and translations, and forcefully argued for the language's autonomy, dignity, and expressive potential. While early romantic Ukrainian writings were seen as colourful linguistic and ethnographic regional variants useful for the development of Russian imperial and national culture, the growth of Ukrainian literature alarmed both Russian critics and administrators, who began to see in these developments not only unproductive and anachronistic vexations, but also a culturally and ideologically subversive agenda that had to be discouraged. By surveying and examining diverse classifications and discussions of the Ukrainian language by Ukrainian and Russian literati, the article questions the limits of so-called "Ukrainophilia" in Russian imperial culture of the early nineteenth century.
\end{abstract}

Keywords: Russian Empire, Ukrainian language status, dialect, literary language, mimicry, language politics.

$\mathrm{T}$ his article ${ }^{1}$ explores characterizations of the Ukrainian language in the cultural discourse of the Russian Empire in the first decades of the nineteenth century, a transitional period before the advent of romanticism. A quick glance through statements commenting on the Ukrainian language reveals a daunting range of opinions, seemingly irreconcilable, circling

\footnotetext{
${ }^{1}$ Research for this article, which forms part of a larger project, was supported by the Social Sciences and Humanities Research Council of Canada.
} 
around a number of key issues: Is Ukrainian a language? Is it a dialect, and if so, a dialect of what? How different or distant is it from Russian (and how comprehensible to a Russian)? Is it old or modern, dead, dying or alive, pure or contaminated? Where is it found and what is it to be named: Little Russian, Ukrainian, Southern-Russian? Should one record, study, codify, use (and for what?), ignore, or discourage it?

Sometimes we find these questions within the same text, as if the author held off answering through hesitation, circumlocution, and ambiguity. After all, in the nineteenth century, questions and propositions about the Ukrainian language never existed in isolation, as purely linguistic issues but were always connected with larger processes: the shaping of Ukraine as a legacy, polity, and indeed, policy or strategy within the political, social, and cultural body of the Russian empire. Members of the Ukrainian elites and intelligentsia, who were integrated (or integrating) into the imperial social fabric after the abolishment of the Cossack Hetmanate, actively engaged in this process, eagerly promoting their cultural and social capital while adjusting to new circumstances (Kohut, Russian Centralism; Saunders; Plokhy). I concentrate on the perceptions and conceptualizations of the Ukrainian language and the values and functions assigned to it by participants in this Ukrainian-Russian cultural exchange. At the core of this reciprocal process we observe what Zenon Kohut called the paradigm of Russo-Ukrainian unity and Ukrainian distinctiveness, that is, attempts by Ukrainians to position their cultural capital as a uniquely privileged complement of Russian culture and as necessary to the development of Russian (russkii as pan-East-Slavic) civilization within the political framework of a powerful and ambitious empire ("The Question of RussoUkrainian Unity"). In other words, the claim that the Ukrainian component was essential to a thus diachronically and teleologically perceived Russianness was based on a difference from Russians (Great Russians), which Ukrainians advanced as a positive distinction. ${ }^{2}$ The difference evoked the historical and cultural tradition to which they were emotionally and nostalgically attached, yet it was to be erased in the unfolding historical process. Moreover, this difference also recalled the conflict-ridden and traumatic aspects of the Ukrainian-Russian historical encounter (the curse of Mazepa occupying a central place in the shaping of the Ukrainian national character and Ukrainian-Russian reciprocity). ${ }^{3}$ The delicate balancing of oneness with Russia and otherness from Russia affected the place and role of the Ukrainian language in conceptualizations of Ukraine. It should not

\footnotetext{
2 On the dialectics of difference as deviation or distinction in the behaviour of groups, see Bourdieu 22-23, 62-65.

${ }^{3}$ For more on these issues see Koznarsky, "Obsessions with Mazepa."
} 
surprise us then that the Ukrainian discourse (produced in Russian and Ukrainian, mostly by Ukrainians) abounds in contradictions. This discourse is by definition self-conscious, self-monitored, double-sided, and expressed through mimicry's "forked tongue" (Bhabha 85)-incorporating cultural and ideological paradigms that often run amok, regardless of whether a text is intended to be subversive.

Ukrainian Language As Legacy and Strategy: Balancing Acts in the Age of EMPIRE

The place of language in the conceptualization of Ukraine can be clearly observed at the turn of the eighteenth-nineteenth centuries in several projects that emerged in Ukrainian circles in Petersburg and Left-Bank Ukraine. These projects were undertaken by the Ukrainian elites to promote their social and cultural capital at a time when the last vestiges of Ukrainian autonomy had been eliminated. Iakiv Markovych's geographic and ethnographic description of Ukraine Zapiski o Malorossii, eia zhiteliakh $i$ proizvedeniiakh (Notes on Little Russia, Her Inhabitants and Products, 1798) was planned as the first installment of a larger series of scientific Ukrainica. ${ }^{4}$ Markovych explores a wide range of interrelated dimensions that determined Ukraine's special qualities as a cradle of all the Russians: ${ }^{5}$ the historic past and way of life of Ukrainians are linked to Ukraine's natural environment-topography, climate, vegetation. Thus the cultural resources of Ukraine (wealth of history, virtuous mores) are mirrored by the richness of its natural resources (rivers, soil, and minerals). The Ukrainian language, in turn, was shaped by Ukraine's natural setting and reflects the noble origins of the Ukrainians, their turbulent history, and their sensitive character:

In ancient times, the inhabitants of Little Russia spoke a Slavonic language ("iazykom Slavenskim"), but they lost or corrupted it in the times when they were the captives of the Tatars, Lithuanians, and Poles. Nonetheless, in the current Ukrainian language, or properly speaking, dialect, one still observes certain nuances reflecting both the beneficial climate and tender soul of its speakers. If one throws out all of the crude words used by simple folk ("prostoliudin"), excludes borrowings from the Germans, French, and Crimean Tatars, and then forms a judgement about it, about its spirit-it must be admitted: [the Little Russian language] is tender, pleasant and full

\footnotetext{
4 These plans were cut short by Markovych's untimely death (suicide) in 1804 at the age of twenty-eight.

5 “Kolybel' Rossov," see Markovych 2.
} 
of emotional expressions and diminutives that originated of course from nothing other than the sensitivity of its inventors. One could call it the language of love or at least very apt for vivid expression of feelings of love. (Markovych 57-58) ${ }^{6}$

This description, oscillating in its use of the terms "language" and "dialect," displays an interesting dichotomy. On the one hand, this language-dialect includes the peasant vernacular, and Markovych was all for "civilizing" and purging it of crudities (this attitude toward the peasant language reflects common rationalist views of the age of enlightenment). On the other hand, when Markovych imagines purging the Little Russian language of borrowings from German, French, and Tatar, he certainly is not discussing the vernacular. The language or speech containing these borrowings belonged to the upper strata of Ukrainian society, the language spoken by the Ukrainian gentry and descendants of the Cossack elites. Thus, Markovych posits Ukrainian as a national language (and ancient national heritage) that encompasses, lives within, and unites the higher and lower strata of the Ukrainian people. Moreover, for him the most natural and perfect manifestation of the Ukrainian language, revealing special innate Ukrainian qualities, is found in the folk song, complete in its harmony of thought, feelings, and nature. Infused with "Romantic spirit and sentimental sympathy," Markovych's book anticipates the understanding of an organic connection between language, culture, and nation that would become the cornerstone of Romanticism (Tokarev 123). ${ }^{7}$

Mykhailo Antonovs'kyi, a historian and ethnographer who pursued a career in St. Petersburg, inscribed the Ukrainian language into a detailed historical and ethnographic sketch of the "former" ("byvshie") Little Russian Cossacks in an expanded Russian version of Johann Georgi's ethnographic description of the Russian Empire (Opisanie vsekh). How "former," how "gone" did he intend the Cossacks to appear to the reader? And their

\footnotetext{
${ }^{6}$ All translations are mine. In addition to these formulations, Markovych builds upon Opanas Shafons'kyi's ethnographic classification of Little Russians as comprising northern ("Litviny"), southern ("Ukraintsy," "Stepoviki," "Poleviki"), and "middle" groups, providing details regarding their characteristics, including language (see Horlenko, Narysy z istorii 122). Markovych qualifies the middle-Ukrainian variety as "the best and most pleasant" and describes the dialect of the northern "Litviny" (inhabitants of the territories of Polissia and Volhynia, bordering Belarus) as "tickling the ear" of other Ukrainians and similar to the Gascognian and Swabian dialects of French and German $(65,68)$.

7 In fact, Markovych's reading undertaken in preparation for his Zapiski included Herder's Ideen zur Philosophie der Geschichte der Menschheit (from which he made notes about the Slavs) - a book that had not yet become a standard lecture of Russian ethnographers and intellectuals of the time. See Lazarevskii 359-60.
} 
language in this context-was it to be seen as a rapidly fossilizing souvenir? Antonovs'kyi defined their dialect as a Slavic language-amalgam maintained from ancient times, with Polish admixtures (Georgi, Opisanie vsekh 4: 344). ${ }^{8}$ And yet he also described three dialectal varieties of that same dialectdialects of a dialect? ${ }^{9}$ The discrepancies in Antonovs'kyi's treatment of Ukrainian should not be seen as linguistic naiveté but rather as a strategy of mimicry. This strategy is evident in his description of the "correct, soft, pleasant, and refined pronunciation of the Russian language" as spoken by educated Ukrainians, and in his recognition of their full mastery of Russian in written and spoken forms (Georgi, Opisanie vsekh 4: 344). Here, Antonovs'kyi is asserting the full linguistic adequacy of Ukrainians in the Russian imperial system, thus reflecting upon and contravening the common Russian perception of the Ukrainian accent as a defect. ${ }^{10}$

Both Markovych and Antonovs'kyi characterize and define the Ukrainian language in the context of larger historical and geographic balancing acts that facilitated Ukraine's integration into the Russian imperial body; in this inevitable integration, they promoted the Ukrainian element as an exclusively privileged facet within Russianness itself.

8 This page belongs to a section written by Mykhailo Antonovs'kyi. The original publication in German did not contain these sections (Georgi, Beschreibung aller Nationen). On Antonovs'kyi's participation, see Tokarev 125-31; Horlenko, Stanovlenie ukrainskoi etnografii 44-46.

${ }^{9}$ On the hierarchy of languages/dialects and the linguistic market, see Bourdieu 6869.

10 On the importance of linguistic competence as a "statutory" rather than a simply "technical" capacity in the competition for symbolic capital and access to power, see Bourdieu 69. Antonovs'kyi's curious emphasis beyond a doubt contradicts the perception of the Russian imperial elites of the Ukrainian accent as odd or distorted Russian. Moreover, Antonovs'kyi dedicates significant space to a critique of contemporary Russian gentry for their adoption of the French culture to such a degree that they reject native Russian customs and even forget their native language (Georgi, Opisanie vsekh 4: 142). Thus he reshapes the dichotomy of Ukrainian and Russian languages by privileging the former and characterizing the Ukrainian way of communicating in Russian as superior. This linguistic nuance further contributes to Antonovs'kyi's extensive treatment of Ukrainians: while Ukrainians (defined as "former Little Russian Cossacks") seem to constitute a separate estate and a branch of the imperial peoples, in reality they are really just native Russians ("te zhe Rossiany"), known from the times of Nestor and autochthonous to Little RussiaUkraine (Georgi, Opisanie vsekh 4: 197). It is this positioning of Ukrainians within the Russian empire as part of the core population (Kappeler 172-73) that allowed the Ukrainian gentry and intelligentsia to participate actively in empire-making yet also assert their "special case" as a valuable, unique element within this core population. 
In contrast to these integrative attempts, Ivan Kotliarevs'kyi's Eneida (Aeneid) (first edition, St. Petersburg, 1798) proposes a more radical path by virtue of its purposefully, albeit playfully, declared divergence and selfsufficiency: the title Malorossiiskaia Eneida (Little Russian Aeneid), which appears on the book cover and the front page, defines the work as Aeneid "dressed" in the Ukrainian language (Eneida na malorossiiskii iazyk perelitsiovannaia). ${ }^{11}$ Eneida provided proof of the existence of Ukrainiannarrative and linguistic, universal and subversive at once-at the time of the imperial integration of Ukraine. By transposing Aeneas's adventures and vicissitudes into the Ukrainian vernacular, Kotliarevs'kyi created a mirror of the Ukrainian national experience and a "verbal metaphor for the entire Ukrainian ethos" (Grabowicz, Toward a History 47-48). Eneida's witty, rich, and pliant language produced an extensive and attractive cultural index of Ukraine - a vocabulary, to paraphrase Tamara Hundorova, that implied a national narrative. ${ }^{12}$ As a book designed to fit the low-style comical genre of the Russian literary hierarchy of the time, Eneida was also furnished (by the publisher) with a glossary of 972 words to help the curious reader not versed in Ukrainian-one of the first Ukrainian lexicographic attempts.

Eneida provided a more lasting and compelling case for the Ukrainian language and Ukraine as a legacy than the contributions of Antonovs'kyi and Markovych because it was a literary work of quality, the affirming message of which was conveyed not by cautious reasoning but through its very linguistic and narrative form, ripe with cultural mythology. Eneida ushered in not just a series of imitations, but a vernacular diction or style, the socalled "kotliarevshchyna," that shaped modern Ukrainian literature and its early reception and admission to the imperial cultural market as comic-a legacy against which the next generation of Ukrainian literati had to struggle. ${ }^{13}$ Yet paradoxically, it also answered the serious desiderata advanced by Kotliarevs'kyi's predecessor, Opanas Lobysevych (1732-1805), whose travesty of Virgil's Bucolics, "Vergilievy Pastukhi v malorossiiskii kobeniak pereodetye" ("Virgil's Shepherds, Dressed in Little Russian

\footnotetext{
11 See the first 1798 publication online at irbis-nbuv.gov.ua/dlib/item/0000037.

12 Hundorova points out that Kotliarevs'kyi, while avoiding direct naming of Ukraine/Little Russia, affirms this name by providing numerous signifieds of Ukrainian life, history, and language, and by the metonymic accumulation of attributes, roles, and relationships that actualize the immanence of Ukraine's national existence (126-29).

${ }^{13}$ Literature on Kotliarevs'kyi and his Eneida is too extensive to survey here. Kyryliuk provides a useful overview while Aizenshtok in "Kotliarevshchyna" examines the effects of Eneida on the early nineteenth-century Ukrainian home-grown literati, readers-turned-writers.
} 
Overcoats") remained in manuscript and did not survive. ${ }^{14}$ In 1794, Lobysevych requested vernacular interludia from the archbishop Hryhorii Konys'kyi for publication "for those who know how to find, under the crust of vernacular, the gems of thoughts." Lobysevych further commented on these texts:

Just as with every style of clothing, every dialect has its beauty. For whom even smoke from the motherland is pleasing, the fragrance of native thoughts is most sweet. For the sake of the honour of our nation ("natsii," [emphasis added]), our mother, who has always had men born great or made great through learning and who has produced so many luminaries for our beloved fatherland ("otechestva") ... I ask your Grace to do me this great favour .... and send them to St. Petersburg. Let our Plautus, our Molière contribute to the grandeur of the fatherland ("otechestvu svoemu"). (Petrov 20)

The connection of letters (literature) in a native language to the "honour of the nation" points to a perception of language as a legacy that preserves not just "gems of thought" but ways of thinking, the habitus of the Ukrainian polity (nation), its memory and dignity-which was even more urgent as its political agency and social networks were becoming obsolete in the new imperial framework. ${ }^{15}$ Kotliarevs'kyi's Eneida indeed fulfilled these ambitions, as suggested by its further publication (1798, second ed. 1808, third authorized ed. 1809, complete posthumous edition 1842), its manuscript versions, and its place in the Ukrainian literary tradition. It also brought a degree of prestige to its creator, who was recognized as a local celebrity, visible in Ukrainian administrative circles and among Ukrainian and Russian literati. ${ }^{16}$ The Grand Duke Nicholai Pavlovich, the future emperor, not known as a most avid reader of literature, met the writer and received a copy of his book during his travels through Ukraine in the summer of 1816. "As a clever joke, even we Russians, read Kotliarevs'kyi's Eneida with pleasure"-asserted Nikolai Polevoi in the 1830s (Review of Chary 55). How accessible was Eneida, familiar as a travestied narrative yet rich in

\footnotetext{
14 See Ohloblyn 137-49; Kyryliuk 120-24.

15 See also Marko Pavlyshyn on Eneida playing a part in the process of selfidentification and self-definition of the Ukrainian gentry in the early nineteenth century: "The narod of the Eneida is an idyllic and heroic postulate-a mythical creation .... The reader is invited to define himself as member of a community that transcends class boundaries and is united by custom and historical tradition .... Eneida's persuasive strategy is to reform the reader's residual and historically irrelevant sense of identity with a defunct military caste into a sense of identity with a living nation" (22).

16 See, for example, the extant epistolary sources on Kotliarevs'kyi in Rotach.
} 
specific Ukrainian ethnographic and idiomatic elements, to Russian readers? ${ }^{17}$ How successful was its strategy, its mimicry? I propose that "accessibility" depends on the reader's motivations and reading environment: a reader may enjoy a barely comprehensible text for its exotic words and low vernacular joking, for the fun of a guessing game of recognition and safe (in comical context) loss of semiotic control, i.e., for its playful encounter with the Ukrainian other, oscillating between closeness and foreignness.

In a less controlled environment, the difference between Ukrainian and Russian emerges more starkly and less comfortably. Ivan Dolgorukov, a nobleman, administrator, and writer, found himself in a foreign country when entering Poltava province:

I stopped understanding the language of the people ("iazyk narodnyi"); a simple person spoke to me, answering my question, but did not understand me completely, and I needed translation for three words out of his five.... I think many will agree with me that at the point where language of the people stops being comprehensible one encounters the living boundaries ("zhivye urochishcha") of one's motherland ("rodina" [local patria]), and in my opinion, even fatherland ("otechestvo"). Men of state service (bureaucrats) belong to all countries: they are cosmopolitan by their habits, if not spirit, and their dialect ("narechie") is common to everyone. But it is the so-called simple folk ("chern") that defines the living boundaries between kingdoms, tied together by politics. A Lievlandian will always remain a foreigner in Russia, even though both he and I serve the same state ("Derzhave"). (64)

In Dolgorukov's private statement (made with lighthearted caution), the perception of Russia proper (and Russianness) ${ }^{18}$ vis-à-vis empire underscores the imperial anxiety of loss of control over its territorial and cultural body, exposing otherness living within the empire-made palpable by the difference in vernacular languages. ${ }^{19}$ Moreover, if the difference

17 For example, the writer and historian Mykola Kostomarov (of mixed RussianUkrainian background) who grew up in Ukraine and studied at Kharkiv University in the 1830s, wrote about his frustration in not being able to understand Hryhorii Kvitka-Osnov"ianenko's Ukrainian story "Saldats'kyi patret," due to his weak Ukrainian (Kostomarov, Avtobiografiia 102). Would Kotliarevs'kyi's poem have been any easier or less demanding for a native Russian reader?

18 In Dolgorukov, Russianness is implied as instant national (emotional and mental) affinity across social boundaries, based on shared language, culture, and habitus (set of predispositions); hence he is elated when meeting travelling Russian peasants along his Ukrainian itinerary.

19 See also Gorizontov on the notion of "Russia proper" formed in the nineteenth century. 
between Lievland or Kurland and nationally conceived Russia seems selfevident, the Russian experience of otherness in the lands of Little RussiaUkraine is more complicated, if not troubling: after all, this territory constitutes the historical, political, and religious cradle of Russia. The living natural boundaries ("zhivye urochishcha")-geographic landmarks linked to the language of a land's inhabitants - after all, may become frontiers if not borders. ${ }^{20}$ And this is precisely the tension that surrounds the Ukrainian language as a cultural concept and a vehicle of literary (re)production, eliciting complex (and not at all symmetrical) negotiations and characterizations by Ukrainian and Russian writers and intellectuals involved in the making of national communities and a supranational empire.

\section{NeITHER DEAD NoR ALIVE: The FIRST UKRAINIAN GRAMMAR}

Tension internalized characterizes the first grammar of the Ukrainian vernacular, Oleksii Pavlovs'kyi's Grammatika malorossiiskogo narechiia (Grammar of the Little Russian Dialect, St. Petersburg, 1818, written at the turn of the eighteenth-nineteenth centuries). Inadequate it may be: some criticized its cursory character ("chuda mluvnice," Šafárik noted), ${ }^{21}$ someits particular focus on differences between Ukrainian and Russian. Mykola Kostomarov did not even mention this book in his seminal survey of Ukrainica, "Obzor sochinenii, pisannykh na malorossiiskom iazyke" ("Survey of Works Written in the Ukrainian Language," 1843). On the other hand, George Shevel'ov viewed this brief grammar, with its appended sizeable lexical, idiomatic, and literary corpus, as a quasi-almanac, or even silva rerum (193-94). In other words, it is a work that displays the difficulty, the precarious ambiguity, of its own position, purpose, and message-a work of cautious and often ambivalent negotiation of not only the Ukrainian language but of Ukrainianness itself-that is, Ukraine's character and tradition, its place and destiny in the Russian empire and universal civilization. Pavlovs'kyi situates Ukrainian as a vanishing, secondary, deviated version of the mainstream imperial language while cautiously endorsing its value and variety, as well as its potential and applicability in

\footnotetext{
20 This ultimate terror of the Ukrainian language as a vehicle of political separatist agency evolved throughout the nineteenth century, and was vividly captured in Vladimir Korolenko's essay "Kotliarevskii i Mazepa" (1916) where reactions of conservative Russian circles to the construction of a monument to Kotliarevs'kyi in his native city of Poltava are defined by the phrase: "Na sem iazyke govoril prokliatyi Mazepa [the cursed Mazepa spoke this language]" (374).

21 Šafárik 29. Bodians'kyi, Šafárik's consultant in things Ukrainian, also saw it as a "weak sketch" ("Rassmotrenie razlichnykh mnenii," 488).
} 
slovesnost', the highest verbal activity and legacy of a people ("narod"). The subtitle of his book defines the author's task: to display "the most salient differences that have distanced the Little Russian dialect from the pure Russian ('Rossiiskogo') language."22 This "purity" of imperial language instantly positions the subordinated (colonial) dialect as impure or contaminated, while the difference between Ukrainian and Russian is negotiated in terms of distancing, at once stressing the common roots of both languages yet positioning Ukrainian as a deviation from these roots and from the normative imperial language (and even discourse). ${ }^{23}$ While referring to the Little Russians as a people by a capitalized ethnonym ("Malorossiiane"), he renders their territory as a "small" realm of a single imperial body: little Russia ("malaia Rossiia," as opposed to "Malorossiia"; emphasis in the original) (Pavlovskii, "Vmesto predisloviia," i). The internalized colonial power relationship and mechanisms of mimicry permeate Pavlovs'kyi's grammar and shape not only his descriptive, definitional apparatus, but even his identity: he obliquely refers to himself as an outsider who has lived among the Ukrainians and is motivated to write about them through intellectual curiosity. ${ }^{24}$ Shevel'ov argued that Pavlovs'kyi (born 1773, died after 1822) was a Ukrainian associated with the Novhorod-Siverskyi circle of Ukrainian activists of the late eighteenth-early nineteenth centuries (18284, 191-93). ${ }^{25}$ If we accept this hypothesis, Pavlovs'kyi intentionally obscures his ethnic or national identity and describes the Ukrainian

\footnotetext{
22 Book cover (no pagination).

${ }^{23}$ See Bourdieu 46-47, and esp. 50-57, on the role of the official (legitimate) language in the political unification and devaluation and suppression of dialectal or sociolectal differences.

24 Thus Ukrainians are for him "a close neighbouring people," "dear compatriots who come from the same roots as myself" among whom he had lived several years (Pavlovskii, "Vmesto predisloviia," ii).

${ }^{25}$ A graduate of the Kyiv Mohyla Academy, he continued his studies in the 1790s at St. Petersburg Teachers' Seminary. Upon his graduation in 1793, he entered the civil service, probably under Prince Oleksandr Bezborod'ko, later reaching the rank of court councilor ("nadvornyi sovetnik"). Most likely, he started working on his Ukrainian grammar in Petersburg in 1792-93. He submitted it to the Russian Academy of Sciences for publication in 1805, but the academy did not publish the work. We do not know whether Pavlovs'kyi's grammar of 1818 introduced changes to his 1805 version, and whether his introduction, for example, was written for the 1818 publication or in the early 1800s. Most likely, the latter is the case, since all literary works (examples of literary application of Ukrainian) mentioned by Pavlovs'kyi belong to the last decades of the eighteenth century. By 1818, he would have been familiar with some new works in Ukrainian by Kostiantyn Puzyna, Hryhorii Koshyts'-Kvitnyts'kyi, Petro Danylevs'kyi and with several poems whose authors remain unknown.
} 
language in a way that precludes a controversial ideological interpretation, blurring the definitions of Ukrainian as a dialect that "almost constitutes a true language" - a language, "so to say, neither dead nor alive."

This defensive armature might seem strange to a student of the Romantic era, yet one must remember that Pavlovs'kyi pursued his project at the turn of the eighteenth-nineteenth centuries in the context of decisive defeats of Ukrainian autonomy and autonomous aspirations. ${ }^{26}$ Romantic fascination with colourful local speech and ethnographic detail was still to emerge over the coming decade in Russian imperial culture. As of 1818, vernacular or folk culture, whether Ukrainian or Russian, was commonly considered low-brow trifle (for example, Pushkin's Ruslan i Liudmila had its share of puzzled reviews). As in many (or most) Ukrainian projects, the double-tongue of mimicry causes Pavlovs'kyi to navigate, if awkwardly, between audiences, horizons of expectations, and messages that were irreconcilable and at times in outright conflict.

In Pavlovs'kyi, the presence of the "imperial eye" (to use Mary Louise Pratt's metaphor), the suspicious and investigative cultural authority, manifests itself through questions directed at his very project, incorporated in the text itself: if one can be occupied by various languages and dialects, "why not Ukrainian?" "Is it necessary to propose rules of Ukrainian composition?" "What purpose could a grammar of the Little Ukrainian dialect serve?" "Is it necessary to preserve various dialects?" ("Vmesto predisloviia," v-vi; Grammatika 22, 112, 113). In response to this internalized questioning, Pavlovs'kyi takes great care to deflect any suspicion by proposing that preserving languages and legacies of the multitudes of peoples is suitable, enlightening, dignified, and a profitable role for an empire as vast and great as Russia ("Vmesto predisloviia," vi; Grammatika 113-14). He internalizes the subordination of the colonized dialect (impure, distorted, uncultivated) to the imperial language (civilized, normative, and pure). Yet he also underscores those aspects and qualities of the Ukrainian language that matter most for universal and national classification. While he describes Ukrainian vocabulary as saturated with deformities of its original roots and foreign intrusions, he also stresses the "grammatical" difference that "makes Little Russian speech ('rech') so unlike our common language" ("Vmesto predisloviia," v). Moreover, he sees Little Russian words that would grace "our very Rhetoric" as they convey meaning more directly and naturally (Grammatika 107-08).

\footnotetext{
26 The protracted history of his grammar's publication (privately, thirteen years after its review in the Russian Academy) reflects difficulties in the positioning of the Ukrainian language in a positive "scientific" way, desirable for a Ukrainian intellectual. See Shevel'ov 178-79.
} 
Pavlovs'kyi stresses the natural aptness of Ukrainians for composition and their distinctive qualities: a particular fluency, plenitude, and simplicity of poetic invention (Grammatika 23). This poetic spirit present in Ukrainians makes them akin to those enlightened nations for whom literature (the verbal legacy that Romantics label as "Poetry") long ago became the foundation of all other disciplines. ${ }^{27}$ In fact, in his general remarks, Pavlovs'kyi carefully defines Ukrainian as a language. He assesses the statements of Ukrainian patriots who had characterized the language as tender (e.g., Markovych), entering into a complicated argument about the inadequacy of this characterization while in effect noting the existence of a segment of Ukrainian educated society that promotes the virtues and status of its language. ${ }^{28}$ In fact, this discussion allows Pavlovs'kyi to propose a compromise: "Let's first clean up the language of the Little Russians [emphasis added] from all sounds contrary or foreign to its nature, let's give it a suitable form and then advance an accurate verdict" (Grammatika 110). He then presents the available corpus of literary works in Ukrainian and reframes the distance between Ukrainian and Russian. While the work begins with a characterization of the Little Russian dialect as a deviation from the imperial language, it emphasizes the difference between the two languages: "one must be very skilled in the Little Russian language to grasp the value [of Ukrainian literary works], so difficult is the Little Russian idiom!" (Grammatika 111). Finally, he suggests the antiquity of Ukrainian (as a language located around Kyiv and thus connected with its tradition): "While reading the History of the Russian Chronicler, the most venerable Nestor, I felt in many places that one needs to know the language of the Little Russians" (Grammatika 112-13). In sum, despite his cautious balancing of definitions and descriptions of the Little Russian dialect that reflect the imperial hierarchy of languages and dialects, Pavlovs'kyi suggests that Ukrainian is a language of ancient roots and cultural potential, with significant differences from Russian. Not surprisingly, in his review of Pavlovs'kyi's grammar, Mykola Tsertelev, a litterateur and publisher of a famed collection of Ukrainian historical songs, defined Ukrainian as one of the purest dialects of the common ancient Slavic language (rather than Russian) and hence a valuable historical and linguistic resource for the betterment of Russian. ${ }^{29}$

\footnotetext{
27 "Sluzhit soliiu dlia vsekh prochikh nauk" (Pavlovskii 23).

28 He gives examples of harsh Ukrainian expressions, differentiates between the more civilized speech of educated urban groups and rural and dialectal crudeness and lack of cultivation, and underscores the "tenderness of the Ukrainian people rather than language" (Pavlovskii, Grammatika 109).

29 Review from Syn otechestva (1818) reprinted in Pavlovskii (1978 facsimile edition) 116-17.
} 
Why is this dialect- "almost a language," "neither dead nor alive" - so important to Pavlovs'kyi? Why did he want to record at least "a single trace of the vanishing dialect" ("Vmesto predisloviia," ii)? For the imperial audience, it is a matter of curiosity (why is the Ukrainian dialect so different from Russian?) and, as Pavlovs'kyi painstakingly argued, of intellectual and linguistic benefit. However, there is another message, directed at the descendants of the Ukrainian Cossack elites. This message shapes a different definition, urges a different action out of nostalgia: to record, codify, and promote the Ukrainian language, to grasp and preserve its essence (or "character") as a depository of, or indeed a portal to, one's Ukrainian identity. Pavlovs'kyi's universalist desideratum, to preserve every dialect as a unique gift of God, acquires a new meaning when directed to Ukrainians: "Who will show us the true image of our ancestors in olden times if we don't preserve their real way of thinking and their dialect?" (Grammatika 113). Pavlovs'kyi's formulation of Ukrainian as a way of thinking and a "true image" of one's historical ancestry and legacy is further buttressed in his composition of an ethnolinguistic and literary corpus. This second section of his book includes a cross-sampling of the vernacular, mimicking and cataloguing the naïve rural world yet also providing a modicum of literary creativity: it comprises a significant vocabulary of particularly marked Ukrainian words, a list of characteristic Ukrainian first names, a folk song, but also a stylized conversation between farmers, a vernacular poem à la paysan "Vakula Chmyr," as well as a most curious text-a tale of one Little Russian (Otryvok iz istorii odnogo Malorossiianina). ${ }^{30}$ This tale is fashioned as a recollection of a Ukrainian who despite his father's wishes and warnings ("Son! What demon is dragging you to this Muscovy?"), decides to go to Petersburg: "Daddy! They say gold and silver grow there, all the people chirp ['tsvirin'kaiut"] in Latin and know everything about what's going on in the world, and there are a lot of big shots ['pany']" (Grammatika 91). The pull of Petersburg was common to generations of Ukrainians, from Feofan Prokopovych to Mykola Hohol'/Gogol': a desire for career, civilization, and high culture (that includes language: universal scholarly Latin, a dated and provincial idea). The narrator admits that his late father's worries turned out

30 Pavlovs'kyi's glossary, consisting of 1,131 words, qualifies as an important lexicographic contribution to the process of definition and codification of the Ukrainian vernacular. The earliest glossary of Ukrainian (972 words) was appended to the first edition of Kotliarevs'kyi's Eneida (1798) by its publisher Maksym Parpura. Other Ukrainian publications also included vocabularies geared to a general Russian audience lacking familiarity with Ukrainian (Tsertelev, Ivan Kulzhyns'kyi). The first fundamental dictionary of Ukrainian (more than 20,000 words) was produced by Pavlo Bilets'kyi-Nosenko in the 1830s-early 1840s (published only in 1966). See Vasyl' Nimchuk's introduction in Bilets'kyi-Nosenko 6. 
to be well-founded, and his experience of alienation is defined through language:

And so, when I got to Petemburkh, it seemed as like another world ("ne toi svit"): our Cossacks were nowhere to be seen, not even half a person-only Ruskies ("Moskali") and Germans ("Nimota") everywhere, and all of them yak ("kharamarkaiut") in German. Only here and there, you would hear someone saying a word like the ones that our fathers, grandfathers, and ancestors spoke in Konotop, Kremenchuk, Svarkiv, Karyzh, and far beyond Kyiv, near Myrhorod, and all the way to Voronizh. (Grammatika 92-93)

Pavlovs'kyi's narrator is certainly among the predecessors of Gogol"s redhaired Pan'ko (we know that Gogol' read Pavlovs'kyi's grammar), yet instead of the Gogolian theatrical invitation to his metropolitan readers to enter the hut of the beekeeper, Pavlovs'kyi's Little Russian addresses his compatriots and uninvites them from the capital. His tongue-in-cheek definition of St. Petersburg as another world (underworld) is based on the taxonomy of its inhabitants: a total absence of "normal beings" (i.e., members of the same/shared community), and the overwhelming presence of foreigners who speak German (i.e., a foreign language, a non-human, "mute" German language-“nimets'ka, nima"). Ironically, a provincial bumpkin who might have hoped to join in the metropolitan chirping in cultured Latin (as an educated Ukrainian could), ended up in an environment of metropolitan foreign "yakking," which vernacular etymology labels as "nimets'kyi," "dumb." In fact, it is the narrator who feels deaf and dumb in the capital. The protagonist's recognition of occasional single words of his native tongue in the foreign speech of Petersburg implies the presence of Ukrainians who had become acculturated, assimilated, and barely distinguishable from "Germans." In the end, the protagonist's capturing (or even gathering) of alienated Ukrainian words in the metropolitan milieu brings him to the nostalgically imagined fatherland-Ukraine: an organic living community that precisely through a shared and inheritable language unites scores of contemporary Ukrainians with generations of their ancestors (fathers, grandfathers, and beyond). This community is contained in a territory that stretches from remote villages in Chernihiv province ${ }^{31}$ to well-known core Ukrainian loci such as Konotop and Myrhorod, and to the cultural borders of Ukraine (from far beyond Kyiv to Voronizh). This curious topography seems at first glance scattered and disorienting (imitating a loss of perspective, i.e., historic memory), yet the taxonomy of Pavlovs'kyi's choices indicates the opposite: a suggestion of a particular cultural identity and the equality of these Ukrainian settlements and geographic coordinates, smaller and larger,

31 See Shevel'ov 184-85; the scholar conducted detective work in locating these villages. 
known and remote-all made known and equally significant within the stylized organic body of Ukraine, where the shared language and territory forge the nation. While suspending a verdict on the existence of Ukrainian in his editorial-scholarly "alibi," Pavlovs'kyi confirms its vitality through the practical literary application of vernacular, stylized in his tale as a fragment of the anonymous oral naïve Ukrainian world (i.e., "skaz"). The anonymity of names and geographic loci in this tale is intentional, programmatic, and revealing. It conceals its profoundly autobiographic nature. Moreover, the geographic catalogue of "scattered" places conceals the historic dimension and historic roots of Ukrainian identity, articulated through the field of language. While the narrator fully identifies himself with the Cossack nation, in his symbolic-geographic mapping of Ukraine, he does not mention the places with the most marked and well-known connections to Cossack history (Baturyn, Poltava, Hlukhiv, Chyhyryn). These purposeful, in my opinion, strategies suggest historic loyalties through the very gestures of decentring and mimicry - in short, the mechanisms that necessitate and tie together the philosophical, linguistic, and literary aspects of Pavlovs'kyi's special enterprise. In other words, through its careful sequence of definitions, queries, reservations and propositions, linguistic patterns, ethnolinguistic examples, and literary stylizations, Pavlovs'kyi's grammar achieved nothing less than the affirmation of Ukraine through language.

\section{QUESTIONING THE NORM}

Between 1805 (when Pavlovs'kyi submitted his grammar of Ukrainian to the Russian Imperial Academy) and 1818 (the year it was published privately), there was in an obvious sense little growth in the field of Ukrainian language and literature, yet this initial impression, and indeed the notion of growth, is deceptive, especially if we apply to this transitional period the organicist expectations and conditions of the Romantic era. How much of this is knowable? Are we to judge the state of Ukrainian culture at the time by the number of Ukrainian books? How do we define Ukrainian books prior to and during the emergence of the literary market in the Russian Empire? Research into everyday cultural forms and needs of Ukrainian society might provide further insights into this problem. So far we have only a few shards and traces: testimonies about circulation of manuscripts of Eneida (several were preserved) and the facts of its republications (1808 and the authorized edition of 1809); "kotliarevshchyna" as a dilettante literary activity of Ukrainian readers; songs and manuscripts collected, copied, and produced by Ukrainian gentry. Certainly the establishment of Kharkiv University, triggered by grassroots local activism, and the emergence of the first 
journals in Kharkiv, suggest significant cultural stimuli. ${ }^{32}$ Ukrainian elites continued to define and maintain their identities, and their past, traditions, and language remained central to their private lives, careers, and family connections, and to their pursuits, longings, and pastimes. The readiness of Ukrainian literati and the eagerness with which they rode the romantic wave from the late 1820s throughout the 1830s, shaping that special place of Ukraine in the Russian cultural imagination, suggest a continuity of the ideas, concerns, and classificatory strategies we observed in Markovych, Antonovs'kyi, Pavlovs'kyi, and Kotliarevs'kyi. The institutional, social, and cultural limbo ("neither dead nor alive") of the Ukrainian vernacular triggered further visitations, revisions, and touchy feelings. In his article gauging the status of the Polish, Czech, and Russian languages, the Polish historian, bibliographer, and philologist Jerzy Bandtkie, a professor at Kraków Jagellonian University, used Ukrainian to "decentre" the exaggerated, in his opinion, antiquity and cultural dominance of Russian. ${ }^{33}$ Bandtkie argued that according to evidence provided by the Ukrainian glossary appended to Kotliarevs'kyi's Eneida (impressively substantive and extensive in documenting the differences between Ukrainian and Russian) and to historic evidence (for Bandtkie, the capital of the Ukrainian language is found in ancient Kyiv),

the Little Russian language does not yield to Great Russian in antiquity and cannot be considered a dialect of the latter.... The Little Russian dialect is older than many others since Kyiv flourished at a time when Moscow did not exist, and Slavic Polianians before Riurik spoke none other but their Slavic language. ${ }^{34}$

32 For example, during its first year (1816), Ukrainskii vestnik (Ukrainian Herald) published a significant corpus of materials on Ukraine's history (especially on the Cossack period).

33 According to Bandtkie, "Contemporary Russian could not have emerged before 1147, when Moscow was founded, and could not have garnered much success before the capital [of Rus'] moved [from Kyiv] to Vladimir on the Kliazma and later to Moscow" (118).

34 Thus, Bandtkie sees Ukrainian as the direct descendant of the "original" language of Kyiv and medieval Rus'. He associates the emergence of the modern Russian language with later periods: the establishment of the Romanov dynasty and the pervasive foreign influences of the age of Peter I that distanced modern Russian even further from its original Slavic roots. In short, modern Russian language implicitly appears in this framework to be a relabelled Muscovite language (we should add: as would befit Polish historical tradition and cultural ideology and the place of Rus' in them). By the strategic repositioning of the origins of Russian and Little Russian, Bandtkie wages a critique against a "colonizing" classification (by implied Habsburg and Russian cultural authorities) of Slavic languages (and nations): "German 
The article appeared in translation in the Moscow journal Vestnik Evropy (The Herald of Europe). The editor, Mikhail Kachenovskii, an intellectual and litterateur of Greek descent, born and educated in Sloboda Ukraine and positively inclined toward Ukrainian letters and matters, felt obliged to correct Bandtkie's anachronism: "Slavic Polianians ... could not have spoken the Little Russian dialect since the name Little Russia did not exist then." Curious logic: clearly, for Kachenovskii, the name of a people and the name of their language are interchangeable or indeed the same, in good old Primary Chronicle fashion: nation equals native tongue ("iazyk"). ${ }^{35}$ To Bandtkie's generous and hypothetical wish that the Ukrainian language become one of the enlightened Slavic languages, Kachenovskii replied with a corrective:

[Ukrainian] has not yet been brought under the rules of grammar and in its current state is suitable only for jocular works. . . . The Great Russian language, in which many thousands of books have been published ... is still far from perfection. When, in light of this, could the Little Russian language, with practically only a single work, Eneida, catch up? What purpose could be served by its elevation to the level of an enlightened language, a task linked to insurmountable difficulties? (Bandtkie 123)

Kachenovskii's refutation focuses not only on "empirical data" regarding the Ukrainian language and on the difficulties connected with the refinement of a literary language, but also on the purpose of such an enterprise: literary Ukrainian is not only unachievable but also unnecessary given the course of cultural progress of the Russian empire. This argument and "verdict" reveal a cultural desideratum, a prescriptive structure that remains operative in the shaping of Ukrainian-Russian cultural reciprocity and of Ukrainian and Russian identities. Even today one can trace some Russian media commentaries on recent controversial Ukrainian laws concerning language to see the pattern: the existence and position of the Ukrainian language in the modern world is an important factor upon which the integrity and congruity of the Russian identity itself-Russian origins, language, civilization, polity, nation-pivot. Participants in linguistic discussions become agents of national and civilizational classificatory struggles by definition.

academies, both in Germany and Russia ... while denigrating the Bohemian (Czech) and Polish languages, advance only Russian as a language worthy of respect and even maintain that it was the original common (Slavic) language" (121).

35 Bandtkie 24-25 (footnote by the editor Kachenovskii). Kachenovskii must have believed that these Polianians spoke Russian (even though the term Rus' was used in The Primary Chronicle initially to denote only Scandinavian warriors, merchants, and colonizers of Slavic Polianians et al.). 
The notion of the Ukrainian language as a key part of the Ukrainian legacy and of Ukrainian society is evident in the pre- and early romantic forays into Ukraine. Aleksei Levshin, while a student at Kharkiv University in 1816, published a description of Left Bank Ukraine (i.e., the former Cossack Hetmanate or Little Russia proper), Pis'ma iz Malorossii (Letters from Little Russia), that reveals ample influence of Herderian ideas (Volksgeist, individuality of nations, centrality of language and folk tradition as forces that define a nation). Levshin categorized the Ukrainian language as part of his ethnographic description of Ukrainians-Little Russians. In his estimation, the language of the Little Russians, while originating from the ancient Slavic, absorbed numerous foreign (German, Latin, and Polish) distorted words so that it became nearly incomprehensible to a Great Russian. Similar to Pavlovs'kyi, Levshin oscillates between the designations "dialect" and "language" - and states that if Ukrainian is a dialect of Russian, it is certainly the most distant one. ${ }^{36}$ Levshin registered that only the lower classes preserved the Ukrainian national physiognomy, including the language, as the higher and middle classes assimilated into Russian imperial society. Hence, his conclusions about Ukrainian are highly ambivalent. He surmises that Ukrainian (based on such successful applications as Kotliarevs'kyi's Eneida), if codified, might be brought to the level of languages in the most enlightened nations by local geniuses. Yet he immediately labels such hopes - to weld a language out of a "dialect abandoned by virtually all educated native inhabitants of this land"-as futile (Levshin 78).

Whose hopes and doubts did the eighteen-year-old Levshin reflect-his own or does he reflect sentiments of the intellectual milieu at "young" Kharkiv University? We can speculate, ${ }^{37}$ but one local activist was certainly Petro Hulak-Artemovs'kyi, who published several important poems in Ukrainian in the first cultural periodical in Ukraine, the journal Ukrainskii vestnik (Ukrainian Herald; Kharkiv, 1816-19). Most of the poems employ the genre of the fable, a tale with a moral lesson, and some use the device of travesty. While the moral lessons of these works are conventionally appended or revealed at the end-often offering a daring social critiquethe poems also contain commentaries on their own linguistic medium, cultural orientation, and attitudes toward imperial cultural (and linguistic) norms. These commentaries are shaped as playful, familiar authorial addresses to friends and readers. They poke fun at a stereotyped Russian ("moskal"'), a crude and ignorant figure (or even fixture) who distorts and

\footnotetext{
${ }^{36}$ Levshin 77: "Otdalenneishee narechie iazyka rossiiskogo."

37 Some details about interest in the Ukrainian language and customs among Sloboda gentry and intelligentsia are given in Iarema Aizenshtok, P. Hulak-Artemovs'kyi 3537.
} 
suppresses the Ukrainian printed word, bringing confusion and trouble to the imagined Ukrainian community. ${ }^{38}$ Hulak provocatively subverts the hierarchy of Ukrainian and Russian in his travesty of Horace "Deshcho pro toho Haras'ka" ("Something About That Guy, Horace"), furnished with authorial commentary. The commentary begins as a simpleton's musings on the differences between the vernacular travestied adaptation of the name Horace: "Haras'ko" and the "strange" Muscovite "Goratsii," but quickly ventures into the field of the Ukrainian-Russian historical encounter. The narrator quotes a Muscovite report on the corrupt Hetman Briukhovets'kyi where he is characterized as an "honest man" who is suited to be a Hetman "since while not educated, he is smart and awfully thievish and effective" (60). This gives the narrator reason to ponder not only the difference between "our" ("po-nas'ky," Ukrainian) and "Muscovite" ways of saying things, but the difference between ways of seeing things:

of course, every Christian nation [note humour!] speaks its own way: In Turkey-Turkish, in Germany-German, yet our deacon in Prechystianka read in a book that if someone is a thief, he is called a thief everywhere-in Germany as well as in Turkey, unless, well, somewhere it is otherwise." (60)

What this tongue-in-cheek "naïve" musing suggests is the reversal of the linguistic and cultural hierarchy in a form much more direct than Pavlovs'kyi's musings or Levshin's ambivalence. The Ukrainian (ours) and the Russian (Muscovite) languages are not just different or distant, they imply opposite sets of predispositions. Moreover, it is "our" simple language that is "normal" and universal in its system of values and that is comparable to other civilized languages, be it German or Turkish-it is the Russian (imperial) language that is a distortion. Hulak's playful authorial piece is nothing less than a Ukrainian symbolic retaliation in which the notions of distortion and deviation (commonly applied by the colonizing standard linguistic authority to the colonized speech) are amplified and redirected toward the imperial "norm" itself. Perhaps not surprisingly, even in the fairly lax environment of university-administered censorship (before the imposition of a much stricter censorship code in 1826), this passage was omitted in the original publication (Hulak-Artemovs'kyi 242). ${ }^{39}$

Ukrainian elites in the post-Napoleonic atmosphere, rife with political ambitions and cultural anxieties, found their most powerful expression in an enigmatic and mimicry-laden work, an ardent anonymous polemics shaped as a chronicle-Istoriia rusov (History of the Rus' People). Written in Russian most likely in the late 1810s-early 1820s, History of the Rus' People was

\footnotetext{
38 See, for example, his “Suplika do Hryts'ka Kvitky," in Hulak-Artemovs'kyi 48-50.

39 Compare Ukrainskii vestnik no. 11, 1819, pp. 237-39.
} 
attributed to Archbishop Hryhorii Konys'kyi (who died in 1795). The work circulated in manuscript form and had a profound impact on several generations of Ukrainian intellectuals and literati. ${ }^{40}$ In this political tract, the Ukrainian language itself - as far as I am aware-for the first time is directly linked with the persecution of Ukrainians, adding to the list of Ukrainian grievances against the empire recorded therein. Thus, General Secretary Savich was tortured by order of Peter I because the emperor misunderstood Savich's Ukrainian polite reply, taking it for an act of insubordination. Cossacks serving in the Prussian wars were driven by their commanders to consumption and depression for their Ukrainian dialect and accent alone (Istoriia rusov 228, 248). The alibi of a "historical monument" allowed the alleged author to address directly the notion of discrimination of the Ukrainian language as yet another case of national oppression of Ukrainians. In History of the Rus' People, Ukrainian as a means of collective (national) communication that diverges from the imperial norm (Russian), triggers suspicion, colonial denigration, and persecution of its speakers.

\section{AT THE ROMANTIC CROSSROADS}

Opinions about the Ukrainian language voiced with caution, tension, and ambiguity in the first two decades of the nineteenth century become transformed with the advent of Romantic ideas and sensibilities. A decade after the publication of Pavlovs'kyi's grammar, we see a marked shift, if not in the conceptualization of the Ukrainian language, then at least in its reception and evaluation within Russian imperial and nascent national culture. ${ }^{41}$ This section briefly charts the evolution of uses and perceptions of Ukrainian in the Romantic era, when the ambiguous articulations and cautious propositions discussed above were put to work and thus tested the limits of Ukrainian-Russian cultural reciprocity.

Ukrainian folklore spurred the imagination (and even the envy) of writers and critics alike as a manifestation of pure Slavic roots and the national character of the Ukrainian people, the southern descendants of Rus'.42 Mykhailo Maksymovych's collections Malorossiiskie pesni (Little

\footnotetext{
40 On the fascinating and labyrinthine genesis of History of the Rus' People, its pool of ideas and its rootedness in the closely linked milieu of Cossack elites in the RightBank Ukraine, see Plokhy.

41 See also Komarov 132-34.

42 See, for example, reviews of Maksymovych's Little Russian Songs in Severnaia pchela no. 123, 1827; also see Moskovskii vestnik (Shevyrev 310). A detailed list of Ukrainian folklore and ethnographic material published in various periodicals and collections is provided in Andrievs'kyi.
} 
Russian Songs, Moscow, 1827) and Ukrainskie narodnye pesni (Ukrainian Folk Songs, Moscow, 1834) were met with admiration both in Ukraine and in the two imperial capitals, in the grips of Herderian ideas. Yet these publications, however attractive for a metropolitan Russian reader, also raised the notion of linguistic difference, which Maksymovych's etymological (Russian-friendly) orthography and glossary could not suppress. ${ }^{43}$ If folklore made the Ukrainian language a legitimate medium and a subject of study, it also served as a vehicle for Ukrainian writers to explore serious and sentimental dictions in the Ukrainian vernacular and thus to overcome its association with the comical register established by Kotliarevs'kyi. From the late 1820s, Ukrainian writers of several generations (Hulak-Artemovs'kyi, Pavlo Bilets'kyi-Nosenko, Lev Borovykovs'kyi, Opanas Shpyhots'kyi) explored the expressive potential of the Ukrainian vernacular through the genre of folklore-oriented ballads and the medium of translation. These poetic works, published in Russian periodicals and several bilingual (Ukrainian and Russian) almanacs, charted a path toward what earlier ambivalent discussions of the vernacular had called "amelioration" and "cultivation" - the functional, expressive, and thematic assertion of this neither dialect nor language, neither dead nor alive. These translations pushed way beyond the folk-oriented applications of the vernacular and beyond "naïve" reappropriations of Ukrainian themes into their "native" cultural and linguistic environment (as in adaptations and translations of ballads or Pushkin's Poltava). ${ }^{44}$ Translators of Adam Mickiewicz's orientalist "Farys" and pieces from Lord Byron's "Hebrew Melodies," in fact, claimed the universal capacity of Ukrainian, its selfsufficiency (i.e., linguistic and cultural autonomy) and suitability for expressing high romantic ideas. Exploration of Ukrainian themes and Ukrainian material in prosaic genres in Russian by (mostly) Ukrainian and some Russian authors (Vasyl' Narizhnyi, Orest Somov, Hohol'/Gogol', Faddei Bulgarin, and many others $)^{45}$ made it urgent to graft Ukrainian vernacular prose, of which Hryhorii Kvitka-Osnov"ianenko became a recognized pioneer in the 1830s. These literary efforts, along with folkloric and historical enterprises, gave rise to a hybrid (bilingual, Ukrainian-Russian) syncretic Ukrainian discourse, fluid and interactive in the ambitious positioning of Ukrainian cultural capital. In this context, folkloric projects

43 See Shevyrev 313-14. The anonymous reviewer of Maksymovych's Ukrainian Folk Songs exclaimed: "What a pity that the majority of Russians cannot understand Ukrainian songs so full of true feeling and poetry!" Severnaia pchela, no. 179, 1834.

44 This topic requires much more space than can be afforded here. Some aspects of Ukrainian literary translation are addressed in Strikha; Koznarsky, Kharkiv Literary Almanacs.

45 See Sypovs'kyi's voluminous descriptive survey. 
commonly overlapped with and were catalysts of literary and intellectual activities. In his 1827 collection of Little Russian songs, Maksymovych included Hulak-Artemovs'kyi's Ukrainian adaptation of Mickiewicz's "Pani Twardowska," as if inviting Ukrainian poets to follow in his footsteps. When preparing Ukrainskie narodnye pesni (Ukrainian Folk Songs, Moscow, 1834), his second collection for publication, Maksymovych advertised his plans to publish a corpus of Ukrainian poems, ranging from Mazepa to his contemporaries. ${ }^{46}$ Hohol'/Gogol', building upon the success of his Dikan'ka stories, desired to expand his métier and announced his preparation of a multivolume history of Ukraine. Mykola Markevych furnished his collection of poems, Ukrainskie melodii (Ukrainian Melodies, Moscow, 1831), with extensive historical and ethnographic commentaries. Izmail Sreznevskii, a pioneer of Slavic studies in the Russian empire, designed his extensive series of Ukrainica at the intersections of folklore, historiography, archeography, and literature. The Ukrainian histories of Oleksii Martos and Markevych were shaped as spirited narratives.

The historical and political national agency of Ukraine was rethought and transformed by Ukrainian romantic writers into poetic agency, with literature occupying their top priority as a heightened form of expression of the national spirit, the lasting and culturally pregnant legacy of and for the people. As the poet and translator Shpyhots'kyi put it, with a certain youthful naiveté: “[Ukraine's] Cossackdom in the fields of war has been over. No Cossack will put his sword on the scales of fate ever again. Let him now compete in the fields of sweet song; let him voice the thundering past with the peaceful harmony of the kobza." 47 In this context, native language as a medium of song and poetry was intuited by Romantics as a vessel of charismatic power: an instantly bonding, tacitly sensed, emotionally gripping, and divinely sanctioned endowment to the national community in a state of self-awareness (self-making). The lyrical subject of Amvrosii Metlyns'kyi's poem "Ridna mova" ("Native Tongue"), paralyzed (i.e., deprived of agency) when deprived of his native tongue, sees in it immediate access to an entire world where personal and national elements fuse: "the moment I hear my native word: it is as if I hear my family call me, my father, who died fighting with the Cossacks; as if I hear my poor people moaning under the Polish yoke" (Derkach and Kryzhanivs'kyi 175). ${ }^{48}$ In Markevych's Russian-language Istoriia Malorossii (History of Little Russia), the historian gives the charismatic Ukrainian hero Bohdan Khmel'nyts'kyi a voice during

\footnotetext{
${ }^{46}$ See Severnaia pchela, no. 69, 1834.

47 Letter to Izmail Sreznevskii, Moscow 1831; cit. in Koznarsky, "Kharkiv Literary Almanacs," 144.

48 The poem was first published in the Ukrainian almanac Molodyk na 1843 god, pt. 2, Kharkiv, 1843, p. 113.
} 
heated negotiations with Polish envoys and models (that is, "quotes") the hetman's aphoristic replies and mini-speeches in Ukrainian, thus fusing political and linguistic charismas. Markevych makes the reader a witness to a vivid moment of fateful historical choices (1: 219-23).

The status of Ukrainian as a language worthy of historical inquiry and linguistic systematization, and a legitimate medium of literary enterprises, was forcefully endorsed in Sreznevskii's piece "Vzgliad na pamiatniki Ukrainskoi narodnoi Slovesnosti. Pis'mo k Professoru I. M. Snegirevu" "A Glance at the Monuments of Ukrainian Popular Literature. A Letter to Prof. I. M. Snegirev"). Sreznevskii outright rejects any doubt that Ukrainian is a language (and emphasizes that it is not a dialect of Russian or Polish) and asserts that it yields to no Slavic language in its poetic, musical, and painterly qualities (134). Sreznevskii openly addressed the question of whether Ukrainian should become a language of literature and, potentially, Ukrainian society-or should it remain limited to the lower classes where it was destined to vanish in the course of history. Sreznevskii, unlike the ambiguous Pavlovs'kyi and Levshin, answers this question emphatically in the affirmative. Not only is Ukrainian worthy of preservation as a vehicle of valuable lore and heroic historical legacy, but it also demonstrates potential for future literary achievement:

Why should the profound Skovoroda, the simple-hearted Kotliarevs'kyi, the richly imaginative Artemovs'kyi, and the always playful and captivating Osnov"ianenko ... remain alone in the until recently wild desert of Ukrainian Literature? The language of Khmel'nyts'kyi, Pushkar, Doroshenko, Palii, Kochubei, and Apostol should at least carry the glory of these great men of Ukraine over to the next generations. (135)

Sreznevsky thus sees language as a cultural and historical legacy reflecting the inner life of a people-an organic foundation of literary and national life. This line of argument was further expanded by other Ukrainian writers and intellectuals of the 1830s and early 1840s. Iurii Venelin stressed the exclusive historical and cultural parity between Ukrainians and Russians (Southern and Northern Russians), while underscoring the political and demographic impact of their unity. ${ }^{49}$ Kostomarov asserted that Ukrainian constitutes a language (not a distorted Russian dialect) of twelve million speakers, and is represented by a significant and varied corpus of literary works. The title of his article, "Obzor sochinenii, pisannykh na malorossiiskom iazyke" ("A Survey of Works Written in the Little Russian Language," 1843), links literature and language as a self-endorsing, self-

\footnotetext{
${ }^{49}$ He listed ethnic Russians at 22 million and Ukrainians (including those who live beyond the boundaries of the Russian empire) at 20 million: together they constituted the largest people in Europe (Venelin 566).
} 
evident pair of notions. The "natural right" of millions of Ukrainians to have their own language and literature became the cornerstone of Ukrainian populist cultural ideology. Osyp Bodians'kyi defended the antiquity of the Ukrainian language and extolled Ukraine as the "cradle of Rus'" where "there is no place without a [historical] monument, no moment in time without an event," and where one "drowns in the world of . . . national poetry in euphonic and melodious language" (Review of Malorossiiskie povesti 289, 312-13). Metlyns'kyi, in his philological polemic that served as the introduction to a collection of his poems (Kharkiv, 1839), defined Ukrainian as an ancient language spoken over a vast territory-from the river Vistula to the Kuban region-comprising several dialects, and known under the name of Southern Russian or South-Western Russian. By choosing such a designation, Metlyns'kyi stressed the continuity between Little Russian and Red Russian (or Ukrainian and Galician) varieties of the same language (across state boundaries of Russian and Austro-Hungarian empires) and buttressed Ukrainian claims to the legacy of medieval Rus' (Derkach and Kryzhanivs'kyi 177-90). The contributors to the conservative Moscow journal Maiak (Beacon) defended the literary use of Ukrainian as a popular organic regional medium that served the cultural needs and aspirations of millions of Ukrainians, while seeing literary Russian as an artificial common medium that tended to be used by foreign-influenced higher classes whose literature was disconnected from the vast mass of the Russian people (Korsun 72-76).

In this broad range of statements, we observe strategies of classification and privileged positioning of Ukraine by members of the Ukrainian intelligentsia participating in imperial cultural production, in an atmosphere of romantic nationalist fervour. In the 1830 s to the early 1840s, it was possible to shape the Ukrainian discourse as a valuable contribution to the nascent Russian imperial cum national culture; in this guise it could serve as a unique complement to the notion of Russian "narodnost"' (nationality), the key element (and yet at the same time the most debated and ambiguous concept) of the official Russian ideology: the triad of autocracy, orthodoxy, and nationality. Paradoxically, before the life of Russian peasants and lower classes became widely acceptable in high Russian culture, Ukraine served as a ready (already advanced by Ukrainians) and convenient (colonized, exotic, and familiar at once) substitute or model for the elusive Russian nationality.

The late 1820 s to early 1830 s was a period of imperial cultural infatuation with things Ukrainian, often described as "the Ukrainian fashion" in Russian literature (Zerov 2: 100-07; Grabowicz, Do istorii 92-108). Indeed, the oft-quoted letter of Hohol'/Gogol' to his mother is commonly used to illustrate the cultural wave the young writer rode brilliantly in his Russian language stories on Ukrainian themes: "Everyone is preoccupied with 
everything Ukrainian here [in St. Petersburg]" (10: 142). The correspondence of Gogol"s Nizhyn schoolmate Ievhen Hrebinka provides further commentary on this phenomenon, and on the paths of Ukrainian provincial educated gentry in the imperial capital, the destination Pavlovs'kyi ironically charted in his tale of one Little Russian. Initially worried about his admission into the brave new world, Hrebinka found in St. Petersburg "a colony of educated Ukrainians," marvelled at His Majesty's reported joking in Ukrainian with the Cossack guards at the footsteps of the royal carriage, mused about the secretary of the Academy of Arts Vasyl' Hryhorovych's thick Ukrainian accent after twenty years in the capital and the infatuation of Prof. Solov'ev (the Russian chemist) with colourful Ukrainian words, and carped about the derision of some Russians toward the Ukrainian language (3: 566-68 et passim). The cultural presence of Ukrainians in the imperial centres and their promotion of Ukraine (i.e., cultural and social self-promotion), be it through publications or in the private sphere through literary and familiar circles, necessitated the "fashion" itself: the positioning of Ukraine within the Russian cultural imagination as "something native ('rodnoe'), close to ideal Russianness ('Russko-ideal'nomu')" —an indispensable complement of Great Russia and a key to the Russian Slavic soul that should be revealed to European civilization. ${ }^{50}$

Ukrainian elites and intelligentsia succeeded in promoting Ukraine as a valuable Slavic component and complement of Russianness and contributed to the romantic shaping of the Russian empire as a cultural umbrella and a melting pot where various ethnocultural elements were to flourish and become absorbed in the rich tapestry of imperial civilization. Yet there were limits to the beneficial and indispensable uses of Ukraine. The "ends" or boundaries, in the perception of Russian critics and intellectuals, where the growth of Ukrainian culture ceased to be desirable, were literary applications of the Ukrainian language. The Gogolian example (even a paradigm): a transition from local Ukrainian themes, however colourful, to Russian life, was not suitable for every Ukrainian writer or intellectual, many of whom were preoccupied with the exploration of Ukrainian nationality ("narodnost") as being unique in its own right. The growing "distinctiveness" of the Ukrainian element was threatening to undercut its "unity" with the Russian counterpart. Nikolai Nadezhdin praised Gogol"s tempered sprinkling of Ukrainian words and the ethnographic colour in his Russian prose, and also approved the "fortunate attempts of literary cultivation of the Ukrainian dialect" as fit for enriching the nascent Russian

\footnotetext{
50 See the letter of Andrei Kraevskii (editor of an important journal, Otechestvennye zapiski [Notes of the Fatherland]) to Maksymovych from August 14, 1843 in Danyliv 46.
} 
literary language with pure Slavic elements and regional incrustations, so valuable for imparting this common language with some organic national qualities $(281,436-37) .{ }^{51}$ However, when assessing literature in the Ukrainian language, critics commonly raised the issue of the inaccessibility of these publications to the Russian audience, finding them superfluous, anachronistic, and counterproductive. ${ }^{52}$ Nikolai Polevoi's views of Ukrainian literature provide insight into imperial and national constructions of Russian culture vis-à-vis Ukraine. Polevoi realized the Russian empire's critical need to absorb and assimilate its vast and ethnically diverse territorial acquisitions. However, he also realized the daunting nature of the task, with most of the diverse colonized populations remaining "ours, but not us," including Ukrainians-despite the empire's cooptation of local elites and administrative integration of the Cossack Hetmanate (Polevoi, Review of Istoriia Maloi Rossii 17: 77, 85-86). Yet for Polevoi, these aspects were "normal" signs of imperial growth, ushering in Russia's future civilizational mission. In this scheme, Ukraine-Little Russia provides Russian literature with strikingly dramatic episodes, equal to the best in European history, enlivening the historical narrative of the empire (Polevoi, Review of Istoriia Maloi Rossii 18: 239-40). The critic followed Little Russian literature in Russian (Polevoi, Review of Ivan Mazepa 557), and, moreover, saw literature in the Ukrainian vernacular as a genuinely "naïve" (in Friedrich Schiller's sense) poetic trend benefitting and complementing a Russian literature that was still lacking precisely this organic kind of poetry (Polevoi, Review of

\footnotetext{
${ }^{51}$ Interesting views of the Russian language as such that should embrace vernacular speech and cultural predispositions (while rejecting foreign distortions) were expressed by Vladimir Dal' who advocated that Russians should study Ukrainian in order to model a truly national Russian language that could embrace all social strata of Russian society. In his review of Kvitka-Osnov"'ianenko's Ukrainian stories, the critic argued: "Among us, Russians, the peasant speaks one language; the colloquial language, incoherent and not entirely clear, is different; and the bookish language, divided by style into high, low, medium, jocular, serious, etc.-is again, entirely different. In contrast, the language of the Little Russians has preserved its pristine beauty and strength, and is everywhere identical with itself" (17: 1). This linguistic cum national "utopia," explored in Dal"s playful vernacular stylizations, remained on the periphery of Russian culture.

52 See, for example, a review of Kvitka-Osnov"ianenko's Malorossiiskie povesti in Severnaia pchela, no. 248, 1834; Osip Senkovskii's review of Kotliarevs'kyi's Eneida in Biblioteka dlia chteniia, vol. 56, 1843, pp. 47-48; and several reviews in Sovremennik: no. 38, 1838, pp. 64-66 (on Kvitka-Osnov"ianenko's story "Kozyrdivka" ["Sassy Girl"]); no. 14, 1839, pp. 31-32 (on Sreznevskii's Ukrainskii sbornik [Ukrainian Collection]); no. 15, 1839, pp. 66-67 (on three Ukrainian books, including poems by Metlyns'kyi, and ballads and a play by Kostomarov); no. 27, 1842, pp. 10203 (on Taras Shevchenko's Haidamaky [The Haidamaks]).
} 
Chary). However, this complementary role of Ukrainian literature came, in Polevoi's conceptualization, with a demand to stay within the bounds of the "naïve" - that is, culturally auxiliary and peripheral-devoid of the artifice of reflection and learning (and hence, of its own development). The Ukrainian complement is by definition second-rate, incidental-and thus tolerable. This is why, according to Polevoi, Ukrainian vernacular writers who engage in "history, geography, antiquities" deviate from the role they should play in Russian culture, artificially creating a "false Ukrainian literature" (Polevoi, Review of Chary 55-58, 72). Not surprisingly, Polevoi was alarmed by the poetry of Taras Shevchenko, seeing in Kobzar (St. Petersburg, 1840) a threat that naïve Ukrainian literature was transcending into the realm of "artful" (or in Schiller's terms, "sentimental") poetry: "How can people with talent occupy themselves with such trifles [as artificial Ukrainian poetry]? ... It is a pity to see Mr. Shevchenko deform thought and the Russian language, playing at it a là khokhol!" (Polevoi, Review of Kobzar 836-37). Similarly "wrong" for Polevoi were Ukrainian poets who "having forgotten their native poetic realm [of true folk poetry], translate Mickiewicz, Goethe, Bürger" (Polevoi, Review of Istoriia Maloi Rossii 18: 256). Akin to Polevoi, Vissarion Belinskii strongly opposed notions of Ukrainian literature, history, and nation; he wrote that he would be willing to make one exception to undertake the effort to study and read Ukrainian: for the monuments of Ukrainian folk poetry which he found preferable to Russian folklore (5: 288). This statement reveals an element of the critic's wishful thinking: that Ukrainian become solely a language of monuments of folk poetry, the vehicle for folkloric archeography - the "dead" dialect, fully absorbed into the Russian cultural mainstream and history.

In sum, the critical and polemical interchanges in Russian media in the 1830s and 1840s acutely demonstrate the limits of the Ukrainian cultural discourse and literary "Ukrainophilia": in order to serve a legitimate complementary role in Russian culture, Ukrainian literature had to be "translated" - not simply in language form, but first of all its cultural and ideological orientation must be transformed-a habitus that was imparted to works of the Ukrainian literati, even works that were produced in Russian. The growth of Ukrainian cultural discourse and the development of literary Ukrainian was felt as a threat to the mainstream course of Russian national development. The competition "in the fields of sweet song" was turning into a serious cultural battlefield. Members of the more radically minded (albeit politically innocuous) circle known as the Brotherhood of Sts. Cyril and Methodius advocated for the expansion of the Ukrainian vernacular into the fields of popular education, historiography, and periodical institutions. They envisioned a full-blown literary and intellectual Ukrainian-language realm, a vision that was perceived as threat to the integrity of a Russian empire 
striving for its own nationhood. In the somber and punctilious investigation of the confiscated writings (with the subversive texts translated from Ukrainian into Russian for the higher authorities), the focus (or even fixation) of the "brothers" on the Ukrainian language as the foundation of Ukrainian poetry (in the broad Romantic sense) and society became a red flag to the imperial eye (Butych et al. $1: 80-81 ; 2: 67 ; 3: 20,86) .{ }^{53}$ Pushed to the limits by the strategic and reciprocal shaping of Ukrainian and Russian cultures, the cautious and ambivalent state of the Ukrainian language as "neither dead nor alive" proved to be a bit too "alive" for some. The logical next step was to further delineate the boundaries and impose more categorical desiderata that were shaped in the course of the UkrainianRussian cultural exchange of the nineteenth century and continue to resurface even in today's media confrontations: "never existed, does not exist, and could not exist."

\section{Works Cited}

Aizenshtok, Iarema. "Kotliarevshchyna." Ukraiins'ki propilei, edited by Ia. Aizenshtok, vol. 1, Derzhavne vydavnytstvo Ukrainy, 1928, pp. 5-121.

---. P. Hulak-Artemovs'kyi. Materialy do biohrafii ta istorychno-literaturnoi otsinky. Derzhavne vydavnytstvo Ukrainy, 1927.

Andrievs'kyi, Oleksandr. Bibliohrafiia literatury z ukrains'koho fol'kloru. Vol. 1, Vydavnytstvo Akademii Nauk, 1930.

Bandtkie, Jerzy. "Zamechaniia o iazykakh Bogemskom, Pol'skom i nyneshnem Rossiiskom." Vestnik Evropy, vol. 84, no. 21, 1815, pp. 23-35; vol. 84, no. 22, 1815, pp. 118-24.

Belinskii, Vissarion. Polnoe sobranie sochinenii. Izdatel'stvo Akademii Nauk SSSR, 1953-59. 13 vols.

Bhabha, Homi. The Location of Culture. Routledge, 1994.

Bilets'kyi-Nosenko, Pavlo. Slovnyk ukrains'koi movy. Naukova dumka, 1966.

Bodianskii, Osip (Osyp Bodians'kyi). "Rassmotrenie razlichnykh mnenii o drevnem iazyke severnykh i iuzhnykh russov." Uchenye zapiski Imperatorskogo Moskovskogo Universiteta, no. IX, 1835, pp. 472-91.

--- (pseud. I. Mastak). Review of Malorossiiskie povesti by Grigorii KvitkaOsnov'ianenko (Hryhorii Kvitka-Osnov"ianenko). Uchenye zapiski Imperatorskogo Moskovskogo Universiteta, no. V, 1834, pp. 287-313.

\footnotetext{
53 Especially remarkable is attention given to the epistolary exchange between one of the "brothers," Opanas Markovych, and his cousin Kateryna Kirsten, who rebuked him and his friends for writing in "Little Russian sub-dialect"—an indulgent and selfdelusional enterprise. Impressed with sound thoughts and patriotism of so young a lady, Nicholas I proposed to the head of the Third Department (empire's secret police) Aleksei Orlov that he find a way to financially reward her in the amount of 1000 rubles. (Butych et al. 3: 126).
} 
Bourdieu, Pierre. Language and Symbolic Power. Edited by John B. Thompson, translated by Gino Raymond and Matthew Adamson, Harvard UP, 1991.

Butych, Ivan et al. Kyrylo-Mefodiivs'ke tovarystvo. Naukova dumka, 1990. 3 vols.

Dal', Vladimir (pseud. V. Luganskii). Review of Malorossiiskie povesti, rasskazyvaemye Gritskom Osnov'ianenkom. Severnaia pchela, no. 17, 21 January 1835, pp. 1-4; no. 18, 22 January 1835, pp. 1-3.

Danyliv, Volodymyr. "Do istorii ukrains'koi etnohrafii." Zapysky Ukrains'koho naukovoho tovarystva $v$ Kyievi, vol. IV, 1909, pp. 41-48.

Derkach, Borys and Stepan Kryzhanivs'kyi, editors. Ukraiins'ki poety-romantyky 2040-kh rokiv XIX st. Dnipro, 1968.

Dolgorukov, Ivan. "Slavny bubny za gorami, ili puteshestvie moe koe-kuda 1810 goda." Chteniia v Imperatorskom obshchestve istorii i drevnostei rossiiskikh pri Moskovskom Universitete, vol. 2-3, 1869, pp. 1-355. (Rubric "Materialy otechestvennye") 54

Georgi, Johann Gottlieb. Beschreibung aller Nationen des Russischen reichs: Ihrer Lebensart, Religion, Gebräuche, Wohnungen, Kleidungen und übrigen Merkwürdigkeiten. St. Petersburg, 1776-80. 4 vols.

---. Opisanie vsekh obitaiushchikh v Rossiiskom gosudarstve narodov: Ikh zhiteiskikh obriadov, obyknovenii, odezhd, zhilishch, uprazhnenii, zabav, veroispovedanii $i$ drugikh dostopamiatnostei. St. Petersburg, 1799. 4 vols.

Gogol', Nikolai. Polnoe sobranie sochinenii. Izdatel'stvo Akademii Nauk SSSR, 193752. 14 vols.

Gorizontov, Leonid. "The 'Great Circle' of Interior Russia: Representations of the Imperial Center in the Nineteenth and Early Twentieth Centuries." Russian Empire. Space, People, Power, 1700-1930, edited by Jane Burbank, et al., Indiana UP, 2007, pp. 67-93.

Grabowicz, George G./Hryhorii Hrabovych. Do istorii ukrains'koi literatury. Doslidzhennia, ese, polemika. Osnovy, 1997.

---. Toward A History of Ukrainian Literature. Harvard UP for the Ukrainian Research Institute, 1981.

Horlenko, Volodymyr. Narysy z istorii ukrains'koi etnohrafii ta rosiis'ko-ukrains'kykh etnohrafichnykh zv"iazkiv. Naukova dumka, 1964.

---. Stanovlenie ukrainskoi etnografii kontsa XVIII-pervoi poloviny XIX st. Naukova dumka, 1988.

Hrebinka, Ievhen. Tvory u triokh tomakh. Naukova dumka, 1980-81.

Hulak-Artemovs'kyi, Petro. Tvory. Dnipro, 1964.

Hundorova, Tamara. "Perevernenyi Rym, abo Eneida Kotliarevs'koho iak natsional'nyi naratyv." Suchasnist', no. 4, 2000, pp. 120-35.

Istoriia rusov ili Maloi Rossii. Sochinenie Georgiia Konisskogo, Arkhiepiskopa Belorusskogo. 1846.

Kappeler, Andreas. "Mazepintsy, Malorossy, Khokhly: Ukrainians in the Ethnic Hierarchy of the Russian Empire." Culture, Nation, and Identity. The Ukrainian-

\footnotetext{
54 Since some nineteenth-century periodicals have rubrics (chapter-like units) that have their own paginations, I include a rubric's title in brackets to help a reader/researcher locate the work/page that is referenced.
} 
Russian Encounter (1600-1945), edited by Andreas Kappeler et al., Canadian Institute of Ukrainian Studies P, 2003, pp. 162-81.

Kohut, Zenon. "The Question of Russo-Ukrainian Unity and Ukrainian Distinctiveness in Early Modern Ukrainian Thought and Culture." Culture, Nation, and Identity. The Ukrainian-Russian Encounter (1600-1945), edited by Andreas Kappeler et al., Canadian Institute of Ukrainian Studies P, 2003, pp. 57-86.

---. Russian Centralism and Ukrainian Autonomy. Imperial Absorption of the Hetmanate, 1760s-1830s. Harvard UP, 1988.

Komarov, A. I. "Ukrainskii iazyk, fol'klor i literatura v russkom obshchestve nachala XIX veka.” Uchenye zapiski $L G U$, Seriia filologicheskikh nauk, no. 47, 1939, pp. 125-58.

Korolenko, Vladimir. "Kotliarevskii i Mazepa." Sobranie sochinenii v desiati tomakh, vol. 8, Gosudarstvennoe izdatel'stvo khudozhestvennoi literatury, 1955, pp. 37378.

Korsun, Oleksandr (pseud. A. A. Antypenko). "Kak dumaiut oblastiane. Povest'." Maiak, vol. 3, 1842, pp. 62-76.

Kostomarov, Nikolai (Mykola Kostomarov). Avtobiografiia. Bunt Sten'ki Razina. Naukova dumka, 1992.

---. "Obzor sochinenii, pisannykh na malorossiiskom iazyke." Molodyk na 1844 god, vol. 3, 1843, pp. 157-85.

Koznarsky, Taras. Kharkiv Literary Almanacs of the 1830s: Shaping Ukrainian Cultural Identity. Dissertation, Harvard University, 2001.

---. "Obsessions with Mazepa." Poltava 1709. The Battle and the Myth, edited by Serhii Plokhy, Harvard UP for the Ukrainian Research Institute, 2012, pp. 569-615.

Kyryliuk, Ievhen. Ivan Kotliarevs'kyi. Zhyttia i tvorchist'. Dnipro, 1981.

Lazarevskii, Aleksandr (Oleksandr Lazarevs'kyi). "Prezhnie izyskateli malorusskoi stariny. Iakov Mikhailovich Markovich (1776-1804)." Kievskaia starina, no. 12, 1894, pp. 359-60.

Levshin, Aleksei. Pis'ma iz Malorossii. 1816.

Maksimovich, Mikhail (Mykhailo Maksymovych). Malorossiiskie pesni. 1827.

Markevich, Nikolai (Mykola Markevych). Istoriia Malorossii. 1842-43. 5 vols.

Markovich, Iakov (Iakiv Markovych). Zapiski o Malorossii, ee zhyteliakh $i$ proizvedeniiakh. St. Petersburg, 1798.

Nadezhdin, Nikolai. Literaturnaia kritika. Estetika. Khudozhestvennaia literatura, 1972.

Ohloblyn, Oleksandr. Liudy staroi Ukrainy. Dniprova khvylia, 1959.

Pavlyshyn, Marko. "The Rhetoric and Politics of Kotliarevsky's Eneida." Journal of Ukrainian Studies, vol. 10, no. 1, Summer 1985, pp. 9-24.

Pavlovskii, Aleksei (Oleksii Pavlovs'kyi). Grammatika malorossiiskogo narechiia. Edited by Oleksa Horbach, Facsimile ed., Ukrainian Free University, 1978.

---. "Vmesto predisloviia." Grammatika malorossiiskogo narechiia, edited by Oleksa Horbach, Facsimile ed., Ukrainian Free University, 1978, pp. i-vi.

Petrov, Nikolai. Ocherki istorii ukrainskoi literatury XIX stoletiia. 1884.

Plokhy, Serhii. The Cossack Myth. History and Nationhood in the Age of Empires. Cambridge UP, 2012. 
Polevoi, Nikolai. Review of Chary, ili neskol'ko stsen iz narodnykh bylei i rasskazov ukrainskikh by Kyrylo Topolia. Biblioteka dlia chteniia, vol. 25, 1837, pp. 51-72. (Rubric "Kritika")

---. Review of Istoriia Maloi Rossii by Dmitrii Bantysh-Kamenskii (Dmytro BantyshKamens'kyi). Moskovskii telegraf, vol. 17, 1830, pp. 74-97; vol. 18, 1830, pp. 22457.

---. Review of Ivan Mazepa by Petr Golota. Moskovskii telegraf, vol. 6, 1833, pp. 55557.

---. Review of Kobzar by Taras Shevchenko. Syn otechestva, vol. 2, no. 8, 1840, pp. 83637. On attribution of this unsigned review, see George G. Grabowicz, editor. Taras Shevchenko v krytytsi. Vol. 1, Krytyka, 2013, pp. 611-12.

Rotach, Pavlo. Ivan Kotliarevs'kyi u lystuvanni. Opishne, 1994.

Šafárik, Pavel Jozef. Slowanský národopis. 1842.

Saunders, David. Ukrainian Impact on Russian Culture 1750-1850. Canadian Institute of Ukrainian Studies P, 1985.

Shevel'ov, Iurii (George). "Hramatyka, shcho nalezhyt' do istorii literatury (Hramatyka malorosiis'koho narichchia Pavlovs'koho ta ii avtor)." Slovo: Zbirnyk ukrains'kykh pys'mennykiv v ekzyli, vol. 2, 1964, pp. 177-97.

Shevyrev, Stepan. Review of Malorossiiskie pesni by Mikhail Maksimovich (Mykhailo Maksymovych). Moskovskii vestnik, vol. 23-24, 1827, pp. 310-17. (Rubric "Kritika")

Sreznevskii, Izmail. "Vzgliad na pamiatniki Ukrainskoi narodnoi Slovesnosti. Pis'mo k Professoru I. M. Snegirevu." Uchenye zapiski Imperatorskogo Moskovskogo Universiteta, no. IV, 1834, pp. 134-50. (Rubric “Smes'”)

Strikha, Maksym. Ukrains'kyi khudozhnii pereklad: Mizh literaturoiu i natsiietvorenniam. Fakt, 2006.

Sypovs'kyi, Vasyl'. Ukraina v rosiis'komu pys'menstvi (1801-1850). Vseukrains'ka Akademiia Nauk, 1928.

Tokarev, Sergei. Istoriia russkoi etnografii (dooktiabr'skii period). Nauka, 1966.

Venelin, Iurii. Review of Ukrainskie narodnye pesni by Mikhail Maksimovich (Mykhailo Maksymovych). Teleskop, vol. 35, 1834, pp. 430-44, 506-26, 555-78. (Rubric "Kritika")

Zerov, Mykola. Tvory v dvokh tomakh. Dnipro, 1990. 